\title{
Long-Term Bare Fallow Soil Reveals The Temperature Sensitivity of Priming Effect of The Relatively Stabilized Soil Organic Matter
}

Xiuwei Zhang ( $\square$ xiuwei8689@163.com )

Taizhou University

Biao Zhu

Peking University

Feihai Yu

Taizhou University

Peng Wang

Institute of Applied Ecology, Chinese Academy of Sciences

Weixin Cheng

University of California

\section{Research Article}

Keywords: SOM decomposition, temperature sensitivity, soil microbial biomass, microbial N mining, 13C tracer

Posted Date: August 26th, 2021

DOl: https://doi.org/10.21203/rs.3.rs-836713/v1

License: (9) (1) This work is licensed under a Creative Commons Attribution 4.0 International License.

Read Full License

Version of Record: A version of this preprint was published at Plant and Soil on January 8th, 2022. See the published version at https://doi.org/10.1007/s11104-021-05260-w. 


\section{Abstract}

Priming plays an important role in modifying the decomposition of soil organic matter (SOM), but there are large uncertainties in the temperature effect on priming mainly due to the variation in SOM stability. Long-term bare fallow offers a unique opportunity to isolate the relatively stabilized SOM pool and study its properties. We tested the temperature effect on priming of the relatively stabilized SOM pool by incubating soil samples collected from a bare fallow (representing the relatively stabilized SOM) and its adjacent old field (containing both stabilized SOM and labile SOM) at 10 and $20^{\circ} \mathrm{C}$ for 815 days. We amended the soil samples with $\mathrm{C} 4$ maize leaves to distinguish the $\mathrm{CO}_{2}$ source released from the soils (formed under C3 vegetation) and the substrate added (i.e. maize leaves) based on the natural abundance of $\delta^{13} \mathrm{C}$. In all cases, there was a positive priming effect on native SOM decomposition when fresh organic matter (maize leaves) was added. The temperature sensitivity of priming effect (calculated as the difference in SOM decomposition due to the addition of maize leaves) in the bare fallow soil and the old field soil was quite different: increasing temperature significantly enhanced the magnitude of priming effect in the bare fallow soil, whereas had no effect on the magnitude of priming effect in the old field soil. The increase of the amount of microbial biomass $\mathrm{C}$ by maize leaves application was higher in the bare fallow soil than in the old field soil. Furthermore, for maize leaves-treated soil, temperature increase significantly increased the rate of microbial $\mathrm{N}$ mining throughout the incubation in the bare fallow soil, but had minor effect on microbial $\mathrm{N}$ mining in the old field soil at the end of incubation. We conclude that the priming effect of the relatively stabilized SOM was sensitive to temperature increase, which may be mainly driven by greater microbial growth and microbial demand for $\mathrm{N}$. This work highlights the vulnerability of stabilized SOM to priming effect under global warming and reveals the potential role of microbes in regulating soil $\mathrm{C}$ dynamics under future climate change.

\section{Introduction}

Soil organic matter (SOM) is the largest reservoir of carbon (C) storage in terrestrial ecosystems and its mineralization produces a major $\mathrm{CO}_{2}$ flux into the atmosphere $(\mathrm{Lal}, 2008)$. The $\mathrm{C}$ storage is largely regulated by the plant-derived $\mathrm{C}$ incorporation into $\mathrm{SOM}$ and the release of $\mathrm{C}$ from microbial mineralization of SOM, and even small changes in this balance might largely affect the atmospheric $\mathrm{CO}_{2}$ concentration and global C cycle (Davidson and Janssens, 2006; Lal, 2008). The priming effect (PE), which is defined as the alteration of fresh organic substrate inputs on the decomposition of native SOM, can significantly influence SOM decomposition and nutrient (especially nitrogen, $\mathrm{N}$ ) cycling (Kuzyakov, 2010). Although it is generally recognized that the $P E$ has a large effect on the global $C$ cycle and climate change (Perveen et al., 2014; Vestergård et al., 2016; Guenet et al., 2018), there remain large uncertainties and controversies associated with both the direction and the magnitude of PE (Cardinael et al., 2015; Zhang et al., 2017). A major cause of these uncertainties is the lack of understanding on the PE of the relatively stabilized SOM (Guenet et al., 2012; Cheng et al., 2014). 
SOM can be divided into three $\mathrm{C}$ pools with different stabilities and turnover times: a labile pool (turnover time of several years), an intermediate pool (turnover time of several decades) and a stable $C$ pool (turnover time of several centuries or more) (Davidson and Janssens, 2006; Barré et al., 2010). The intermediate and stable $\mathrm{C}$ pools can be collectively described as a relatively stabilized $\mathrm{C}$ pool with a turnover time from decades to centuries or more (Anderson and Paul, 1984; Jenkinson and Rayner, 1977; Trumbore et al., 1989). This relatively stabilized C pool is the major component of SOM stocks (Davidson and Janssens, 2006) and its vulnerability to the PE can significantly impact the global C cycle (Derrien et al., 2014). Earlier, it was suggested that even the most stable SOM could be rapidly mineralized in the presence of fresh C, such as SOM in deep soil layers (Fontaine et al., 2007) or charcoal (Kuzyakov et al., 2009; Nocentini et al., 2010). Recently, it was shown that the stable SOM is as vulnerable to the PE as is the more labile SOM (Guenet et al., 2012). Later, it was further demonstrated that the PE of relatively stable SOM was more sensitive to elevated atmospheric $\mathrm{CO}_{2}$ (Vestergård et al., 2016), suggesting that the PE has a huge potential impact on the relatively stabilized SOM. Assessing the role of PE on the dynamics of the relatively stabilized SOM under climate warming is yet limited, because to date no study has compared the temperature effect on PE of the relatively stabilized SOM pool with that of the total SOM (i.e. a mixture of the relatively stabilized and labile SOM pools). Moreover, the absence of an adequate understanding on the PE of the relatively stabilized SOM leads to a debate on the temperature sensitivity of PE (Ghee et al., 2013; Frøseth and Bleken, 2015; Lyu et al., 2019).

It is well known that PE correlates with microbial biomass (Thiessen et al., 2013), substrate availability (Chen et al., 2013; Hopkins et al., 2014) and nutrient status (Chen et al., 2013; Feng et al., 2021). Some studies suggested that the response of PE to elevated temperature was short-lived or weak because no changes in substrate use efficiency or active microbial community (Thiessen et al., 2013) were observed under elevated temperture (Ghee et al., 2013; Hopkins et al., 2014). However, this may be different in soils dominated by the relatively stabilized SOM. The stabilized SOM has been widely accepted to be more vulnerable to temperature increase due to its higher activation energy than the labile fraction (Conant et al., 2008; Hopkins et al., 2012; Lin et al., 2015). However, some studies suggested that the temperature sensitivity of the stabilized SOM decomposition may be suppressed because of the accelerated depeltion of available $C$ at elevated temperature (Kirschbaum, 2004; Erhagen et al., 2015). If exogenous labile $C$ input can compensate this available $\mathrm{C}$ depletion due to temperture increase, the activated microbes may accelerate native SOM decomposition through co-metabolism in these soils (Fontaine et al., 2007), which was supported by Zhu and Cheng (2011). Meanwhile, the presence of labile $\mathrm{C}$ may also compensate energy for microorgnisms that specialize in decomposing N-rich SOM to acquire N (Craine et al., 2007; Fontaine et al., 2011). Liu et al. (2019) demonstrated that temperature increase significantly increased the $\mathrm{N}$-acquiring enzymes in labile substrate amended soil, which emphasized the role of microbial community in mediating the response of PE to temperature increase. Therefore, considering the changes in microbial growth and activity and nutrient status may provide mechanistic insights into the temperature sensitivity of PE on the relatively stabilized SOM. 
Separating stabilized SOM from bulk soil is method-limited, but long-term bare fallow treatment provides such an opportunity (Guenet et al., 2012). In the soils without fresh C inputs, the most labile $C$ are prograssively depleted (Barré et al., 2010; Nunan et al., 2015). Comparing paired bare fallow and old field soils would provide insight into the relative vulnerality of the relatively stabilized vs. the total SOM (i.e. a mixture of the relatively stabilized and labile SOM pools) to perturbations such as substrate input and/or temperature increase (Guenet et al., 2012; Lefèvre et al., 2014; Zhang et al., 2017).

In this study, we aimed to test how elevated temperature affects the magnitude of the PE of the relatively stabilized SOM. To differentiate the relatively stabilized SOM from the labile fraction, we used soils from a bare fallow plot which has been deprived of fresh $\mathrm{C}$ inputs for 23 years. We compared the dynamics of the PE under low and higher temperatures in this soil where all SOM was older than 23 years to that in an adjacent old field soil where both the relatively stabilized and labile SOM exist under the same pedoclimatic conditions. We hypothesize that $(\mathbb{\nabla})$ plant inputs may produce positive PE of SOM decomposition due to the activation of the dormant microorganisms by labile substrate input; ( $\mathbb{\nabla}$ ) PE of the relatively stabilized SOM (i.e. bare fallow soil) would be more sensitive to temperature than that of the bulk SOM pool (i.e. old field soil) due to the higher resistence of the relatively stabilized SOM for decomposition under conditions of low substrate availability or temperature. To test these hypotheses, we incubated bare fallow and old field soils at 10 and $20{ }^{\circ} \mathrm{C}$ for 815 days, and applied the natural ${ }^{13} \mathrm{C}$ tracer method to distinguish the $\mathrm{CO}_{2}$ source of native soil and added substrate. Moreover, we measured net $\mathrm{N}$ mineralization, dissolved organic $\mathrm{C}$ and microbial biomass $\mathrm{C}$ to investigate the mechanisms that controlling the response of priming process to temperature.

\section{Materials And Methods \\ 2.1. Soil collection}

Soils were collected from a bare fallow plot and its adjacent abandoned farm plot (old field) of the Hailun Agricultural experimental station $\left(47^{\circ} 26^{\prime} \mathrm{N}, 126^{\circ} 38^{\prime} \mathrm{E}\right.$, and $240 \mathrm{~m}$ above sea level) of Chinese Academy of Sciences (China). This experimental station was located in Heilongjiang province, Northeast China. More details of the site can be found in Zhang et al. (2017). The soil was classified as an Aquic Mollisol (Soil Survey Staff, 1999) with a deep A-horizon and predominantly Montmorillonite clay. Soils from the bare fallow and old field treatments were sampled in Sept. 2012. As part of the coordinated research network, the bare fallow plot had been kept free of vegetation by frequent hand weeding for 23 years at the time of soil collection for this study. Basic properties of these two soils can be found in Table 1 and Zhang et al. (2017). The soil was taken from the top $20 \mathrm{~cm}$. Prior to the incubation experiment, all soils were sieved through $2 \mathrm{~mm}$ screen. Fine roots, plant debris and visible stones were removed carefully. All soil samples were homogenized, air-dried, and stored at $20^{\circ} \mathrm{C}$ before incubation. 
Table 1

Initial properties of the soils and maize leaves prior to the laboratory incubation. Standard error of the mean $(n=3)$ is shown in parenthesis.

\begin{tabular}{|llll|}
\hline Property & Old field & Bare fallow & Maize leaves \\
\hline $\mathrm{pH}(1: 2$ soil: water) & $6.17(0.02) \mathrm{a}$ & $6.01(0.03) \mathrm{a}$ & \\
\hline Clay $(\%)$ & $35.2(0.6) \mathrm{a}$ & $33.8(1.5) \mathrm{a}$ & \\
\hline $\mathrm{SOC}$ content $\left(\mathrm{g} \mathrm{C} \mathrm{kg}^{-1}\right)$ & $35.6(0.1) \mathrm{b}$ & $21.8(0.1) \mathrm{a}$ & $379.0(1.0)$ \\
\hline Total $\mathrm{N}\left(\mathrm{g} \mathrm{N} \mathrm{kg}^{-1}\right)$ & $2.7(0.0) \mathrm{b}$ & $1.8(0.0) \mathrm{a}$ & $13.4(0.1)$ \\
$\mathrm{C} / \mathrm{N}$ & $13.5(0.1) \mathrm{b}$ & $12.3(0.1) \mathrm{a}$ & $28.3(0.2)$ \\
\hline $\mathrm{SOC} \mathrm{S}^{13} \mathrm{C}(\%)$ & $-24.8(0.1) \mathrm{a}$ & $-24.0(0.1) \mathrm{b}$ & $-13.4(0.2)$ \\
\hline SOC ${ }^{14} \mathrm{C}$ content $(\mathrm{MC} \%)$ & 93.1 & 83.6 & \\
\hline SOC ${ }^{14} \mathrm{C}$-age (yr BP) & 575 & 1445 & \\
\hline SOC MRT (yr) & 880 & 1668 & \\
\hline $\begin{array}{l}\text { Means within each row followed by different letters represent a significant difference }(P<0.05) . \text { MC\%, } \\
\text { percent of modern carbon. }\end{array}$ & & \\
\hline
\end{tabular}

\subsection{Experimental design}

Based on previous studies, the soil under the bare fallow treatment for 23 years had lost most of the labile SOM and remained mainly the intermediate SOM as well as the stable pool (Barré et al., 2010). Here we operationally used the bare fallow soil to represent the relatively stabilized SOM (intermediate plus stable SOM pools) and compared the PE of the bare fallow soil with that of the old field soil (i.e. a mixture of the relatively stabilized and labile SOM pools) with two reasons. First, we measured the chemical composition of SOM of these two soils and found that the bare fallow soil had more chemically stable compounds than the old field soil (Fig. 1). Second, we measured the ${ }^{14} \mathrm{C}$ content of SOC (pMC, percent of modern C, Table 1) in these two soils and found that the old field soil was dominated by younger fastcycling $\mathrm{C}$, whereas the bare fallow soil was dominated by older slow-cycling $\mathrm{C}$ which was often referred to as the relatively stabilized fraction of SOC (Jenkinson et al., 1992).

For each soil, $200 \mathrm{~g}$ of air-dried soil was weighed in individual polypropylene column $(5.2 \mathrm{~cm}$ in diameter, $20 \mathrm{~cm}$ in length). Before starting the incubation, soil moisture was adjusted to $60 \%$ of water-holding capacity (WHC) through the addition of deionized water. Both ends of each soil container were closed with one-hole rubber stopper connected to ventilation tubing. A continuous aerobic condition in each plastic container was maintained via automatic timer-controlled aeration with fresh air for one hour in each 4-hour interval during the entire incubation experiment. All soil columns were divided into two amendment treatments: (1) control and (2) substrate-amended treatment. In the substrate-amended treatment, ground maize leaves (sieved through $2 \mathrm{~mm}$ screen) were added the rate of $30 \mathrm{mg} \mathrm{g}^{-1}$ soil. 
The maize leaves were collected from the Shenyang Agricultural experimental station of Chinese Academy of Sciences (China). The $\mathrm{C}$-addition rate was within the range of the normal amount of plant input to the soil in local croplands (Liang et al., 2011). For each amendment, the soil and fresh organic matter were gently mixed and homogenized. Control columns did not receive any maize leaves, and the soils in control columns were mixed and homogenized in the same way as the amended soils. Each treatment was split into two temperature treatments: a cold treatment with constant temperature of $10^{\circ} \mathrm{C}$ and a warm treatment with constant temperature of $20^{\circ} \mathrm{C}$, and were incubated in processor-controlled incubators (SHELLAB LI20-2, Sheldon Manufacturing Inc., Cornelius, OR, USA, with a temperature control accuracy and evenness of $\pm 0.05^{\circ} \mathrm{C}$ ) for 815 days. During incubation, soil moisture was monitored by weighing and frequently adjusted to reach $60 \%$ WHC by adding deionized water. A total of 176 columns with soil were incubated in this study, of which 32 were repeatedly used for soil $\mathrm{CO}_{2}$ trapping (4 replicates for each treatment) and 144 were used for destructive samplings ( 3 replicates for each treatment and 6 destructive samplings).

\subsection{Soil respiration and $\delta^{13} \mathrm{C}$ analyses}

We measured total soil respiration using a dynamic $\mathrm{CO}_{2}$ trapping system with $\mathrm{CO}_{2}$ trapping efficiency greater than 99\% (Lin et al., 2015). Briefly, we used air pump to force ambient air through a soda-lime column, thereby, $\mathrm{CO}_{2}$-free air entered the manifold, from which individual tubing leaded to individual sample inflow tubing. After an equilibrating period of two hours, the subsequent $\mathrm{CO}_{2}$ produced inside the soil columns for $24 \mathrm{~h}$ or longer (if needed) was trapped by the $\mathrm{CO}_{2}$ trapping bottle containing $12 \mathrm{ml} 0.5 \mathrm{M}$ $\mathrm{NaOH}$ solution. Blanks were also trapped to correct for inorganic $\mathrm{C}$ from $\mathrm{NaOH}$ stock solution and sample handling. The $\mathrm{CO}_{2}$ trapping was applied at day $8,14,28,45,60,75,90,128,144,158,187,202,240,263$, $299,330,360,410,480,550,585,630,670,702,756$ and 815, respectively. After $\mathrm{CO}_{2}$ trapping, the $\mathrm{NaOH}$ solution was directly analyzed for total inorganic carbon using multi N/C® 2000 TOC analyzer (Analytik Jena, Germany) and for $\delta^{13} \mathrm{C}$ using cavity ring-down spectroscopy (CRDS) coupled with an Automate Module (Picarro G2131-i Analyzer, Picarro Inc., Santa Clara, CA, USA). The effect of the contaminant C on the $\delta^{13} \mathrm{C}$ value of each sample was corrected according to Cheng et al. (2003).

\section{4. ${ }^{14} \mathrm{C}$ dating and estimation of the mean residence time of SOC}

The ${ }^{14} \mathrm{C}$ content of SOC was measured by the accelerator mass spectrometry (AMS) (1.5SDH-1 AMS, $\mathrm{NEC}$, USA) at the Institute of Heavy lon Physics, Peking University before soil incubation. Before ${ }^{14} \mathrm{C}$ measurements, soil was treated with dilute $\mathrm{HCl}$ to remove carbonates. The ${ }^{14} \mathrm{C}$ content of $\mathrm{SOC}$ is expressed in percent of modern $\mathrm{C}(\mathrm{MC} \%)$, which is the percentage deviation from ${ }^{14} \mathrm{C} /{ }^{12} \mathrm{C}$ ratio of oxalic acid in 1950 . The ${ }^{14} \mathrm{C}$ age was calculated with the Libby half-life (5,568 year) and expressed in years before present (yrBP). The mean residence time (MRT) of SOC was determined according to Fontaine et al. (2007).

\subsection{Fourier-transform infrared spectroscopy analysis}


The molecular composition of SOC was characterized by the Fourier transform infrared (FTIR) spectroscopy (Thermo Fisher Scientific Nicolet iS10 spectrometer, USA) according to Demyan et al. (2012). In detail, $2 \mathrm{mg}$ air-dried ground soil samples ( $<0.147 \mathrm{~mm}$ ) were pressed into $100 \mathrm{mg}$ potassium bromide $(\mathrm{KBr})$ pellets. The spectra were recorded in the mid-infrared range $\left(4000-400 \mathrm{~cm}^{-1}\right)$ by combining 16 individual scans at a resolution of $4 \mathrm{~cm}^{-1}$. The spectra were recorded in absorbance units (AU). The dominant functional groups in the FTIR spectra obtained from the bare fallow soil and the old field soil are illustrated in Fig. S1 and further described in Table S1. The four peaks $(2930,2850,1620$ and $1530 \mathrm{~cm}^{-1}$ ) were selected and assigned to different organic functional groups and their potential stabilities. The peak areas of these four bands were integrated using a tangential baseline from the onset to the offset of each peak, and their relative peak areas of each band were calculated to evaluate the assignments of soil C functional groups (Table S1). The ratio of the peak areas at 1620 and $2930 \mathrm{~cm}^{-1}$ (rA1620/rA2930 ratio) was defined as the resistance index and often taken as an indicator of SOC stability (Demyan et al., 2012; Hou et al., 2019).

\subsection{Chemical analyses}

Microbial biomass $C$ (MBC) was measured at $90,330,550$ and 815 days using the chloroform fumigation extraction method (Vance et al., 1987). Briefly, paired $40 \mathrm{~g}$ soil samples were either extracted with $80 \mathrm{ml}$ $0.05 \mathrm{M} \mathrm{K}_{2} \mathrm{SO}_{4}$ or fumigated with chloroform for $24 \mathrm{~h}$ in the dark and then extracted in the same way. The extract was analyzed for total organic carbon using multi N/C® 2000 TOC analyzer (Analytik Jena, Germany). $\mathrm{MBC}$ was calculated from the difference of $\mathrm{K}_{2} \mathrm{SO}_{4}$-extractable $\mathrm{C}$ between the fumigated and the non-fumigated soil samples using a $\mathrm{k}_{\mathrm{EC}}$ factor of 0.38 (Xiao et al., 2015).

Soil mineral $\mathrm{N}\left(\mathrm{NH}_{4}{ }^{+}\right.$plus $\left.\mathrm{NO}_{3}{ }^{-}\right)$was determined at $28,60,330,550$ and 815 days by extracting $20 \mathrm{~g}$ of fresh soil with $40 \mathrm{ml} 2 \mathrm{M} \mathrm{KCl}$ solution (Lu et al., 2018). After shaking for $1 \mathrm{~h}$ at $200 \mathrm{rpm}$, the mixture was filtered through filter paper and extracts were frozen until analysis. The extracts were analyzed for $\mathrm{NH}_{4}{ }^{+}$ and $\mathrm{NO}_{3}{ }^{-}$using a Continuous Flow Analyzer (AA3, Bran + Luebbe, Norderstedt, Germany). The cumulative

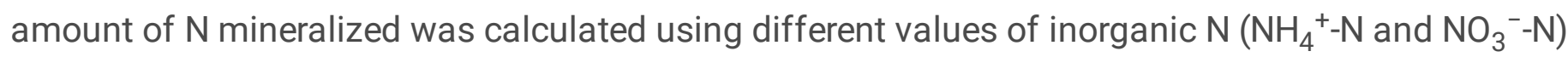
content in the soil before and after incubation in $\mathrm{mg} \mathrm{g}^{-1} \mathrm{TN}$ (Smolander and Kitunen, 2002; Tian et al., 2017; Henneron et al., 2020). Net rates of soil $\mathrm{N}$ mineralization were calculated from the amount of $\mathrm{N}$ mineralized during the incubation divided by the incubation days (Henneron et al., 2020; Song et al., 2011). Soil moisture was measured by oven-drying soil at $105^{\circ} \mathrm{C}$ for $24 \mathrm{~h}$.

\subsection{Calculations and statistical analysis}

The $\mathrm{CO}_{2}$ derived from $\mathrm{SOM}$ and maize straw decomposition were separated using a two-source mixing model (Cheng, 1996):

$\mathrm{C}_{\text {Soil }}=\mathrm{C}_{\text {Total }}\left(\delta^{13} \mathrm{C}_{\text {Total }}-\delta^{13} \mathrm{C}_{\text {Straw }}\right) /\left(\delta^{13} \mathrm{C}_{\text {Soil }}-\delta^{13} \mathrm{C}_{\text {Straw }}\right)(1)$

$\mathrm{C}_{\text {straw }}=\mathrm{C}_{\text {Total }}-\mathrm{C}_{\text {Soil }}(2)$ 
Where $\mathrm{C}_{\text {Total }}$ was the total carbon of $\mathrm{CO}_{2}$ efflux from the substrate amended soil, $\mathrm{C}_{\text {Soil }}$ was the $\mathrm{C}-\mathrm{CO}_{2}$ derived from SOM, $\mathrm{C}_{\text {Straw }}$ was the $\mathrm{C}-\mathrm{CO}_{2}$ derived from the maize leaves. $\delta^{13} \mathrm{C}_{\text {Total }}$ (measured at each sampling time), $\delta^{13} \mathrm{C}_{\text {Soil }}$ (measured at each sampling time) and $\delta^{13} \mathrm{C}_{\text {Straw }}$ are the $\delta^{13} \mathrm{C}$ values of the $\mathrm{CO}_{2}-\mathrm{C}$ from total soil respiration, microbial respiration of SOM and microbial respiration of maize leaves, respectively.

The priming effect $(\mathrm{PE})$ was calculated as the difference between the SOM-derived $\mathrm{CO}_{2}-\mathrm{C}$ in the maize straw-amended treatment with that in the associated control:

$\mathrm{PE}=\mathrm{C}_{\text {Soil (straw-amended) }}-\mathrm{C}_{\text {soil (control) }}(3)$

We used two-way ANOVA to assess the effects of soil land-use type (old field and bare fallow treatments), temperature $\left(10\right.$ and $\left.20^{\circ} \mathrm{C}\right)$ and their interaction on cumulative basal respiration in control treatment, and the effects on total cumulative respiration, $\mathrm{C}_{\text {soil-derived }}$ and $\mathrm{C}_{\text {straw-derived }}$ in amended soils. We used threeway ANOVA to examine the effects of soil land-use type, temperature, sampling date and their interactions on net $\mathrm{N}$ mineralization (NNM), dissolved organic $\mathrm{C}$ (DOC) and microbial biomass $\mathrm{C}$ (MBC) in maize straw-amended soils. We used two-way ANOVA to assess the effects of soil land-use type, temperature and their interaction on the magnitude of PE. Furthermore, we used independent-samples ttest to assess the soil land-use type and temperature effects on the magnitude of PE.

\section{Results}

\subsection{Effects of long-term field treatments on soil properties}

The long-term bare fallow treatment significantly decreased soil $\mathrm{C}, \mathrm{N}$ contents and the $\mathrm{C} / \mathrm{N}$ ratio, but did not significantly affect soil clay content and soil pH compared with the old field treatment. The $\delta^{13} \mathrm{C}$-SOM was more negative in the old field treatment in comparison with the bare fallow treatment. Furthermore, the ${ }^{14} \mathrm{C}$ content of SOC (pMC, percent of modern C) was lower in the bare fallow soil than in the old field soil. The ${ }^{14} \mathrm{C}$ dating and the calculation of MRT of SOC both gave consistent results (Table 1). The old field soil was dominated by younger fast-cycling $C$ (880 year), whereas the bare fallow soil was dominated by older slow-cycling C (1668 year).

Fourier-transform infrared (FTIR) spectroscopy of these two soils generally featured common peaks but showed different intensities (Fig. S1). The relative peak area of $2930 \mathrm{~cm}^{-1}$ and $2850 \mathrm{~cm}^{-1}$ (rA2930, rA2850, representing more labile SOC) in the bare fallow soil was significantly lower than that of the old field soil $\left(P<0.05\right.$, Table S1). The relative peak area of $1635 \mathrm{~cm}^{-1}$ (rA1635, representing more stable SOC) in the bare fallow soil was significantly lower than that of the old field soil $(P<0.05$, Table S1), while there was no significant difference of the relative peak area of $1530 \mathrm{~cm}^{-1}$ (rA1530, representing more stable SOC) between these two soils. The resistance index (ratio of rA1635/rA2930, representing the 
molecular index of SOC stability) was significantly higher in the bare fallow soil than in the old field soil $(P<0.05$, Fig. 1).

\section{2. $\mathrm{CO}_{2}$ emissions from soil and fresh substrate in control and substrate-amended soils}

The mass-specific basal respiration (per unit of dry soil) was significantly higher in the old field soil than in the bare fallow soil, which is in line with the higher SOC content in the old field soil $(P<0.001$, Table 2). The SOC-specific basal respiration was independent of soil land-use type. Moreover, both mass-specific and SOC-specific basal respiration were enhanced by temperature increase $(P<0.001$, Table 2$)$. The total respiration in straw-amended treatment was significantly higher in the old field soil than in the bare fallow soil $(P=0.02$, Table 2$)$, and significantly higher at $20^{\circ} \mathrm{C}$ than at $10^{\circ} \mathrm{C}(P<0.001$, Table 2$)$. However, the SOM-derived $\mathrm{CO}_{2}$ was significantly higher in the bare fallow soil than in the old field soil $(P=0.029$, Table $2)$, and significantly higher at $20^{\circ} \mathrm{C}$ than at $10^{\circ} \mathrm{C}\left(P<0.001\right.$, Table 2). The maize leaves-derived $\mathrm{CO}_{2}$ was significantly higher at $20^{\circ} \mathrm{C}$ than at $10^{\circ} \mathrm{C}(P<0.001$, Table 2$)$, and was similar between the bare fallow soil and the old field soil. 
Table 2

Soil respiration in control and maize straw-amended soils in relation to soil dry weight and initial soil organic carbon (SOC) content, soil-derived $\mathrm{CO}_{2}\left(\mathrm{C}_{\text {soil-derived }}\right)$ and straw-derived $\mathrm{CO}_{2}\left(\mathrm{C}_{\text {straw-derived }}\right)$ in straw-amended soils at the end of incubation in old field and bare fallow treated samples.

\begin{tabular}{|c|c|c|c|c|c|c|c|}
\hline \multicolumn{2}{|c|}{$\begin{array}{l}\text { Soil land- } \\
\text { use type }\end{array}$} & $\begin{array}{l}\text { Basal } \\
\text { respiration } \\
\left(\mathrm{mg} \mathrm{C} \mathrm{g}^{-1}\right. \\
\text { soil) }\end{array}$ & $\begin{array}{l}C_{\text {total }} \\
\text { (mg C } \\
g^{-1} \\
\text { soil) }\end{array}$ & $\begin{array}{l}\mathrm{C}_{\text {straw-derived }} \\
\left(\mathrm{mg} \mathrm{C}_{\text {soil) }}\right.\end{array}$ & $\begin{array}{l}\text { SOC-specific } \\
\text { basal } \\
\text { respiration } \\
\left(\mathrm{mg} \mathrm{C} \mathrm{g} \mathrm{g}^{-1}\right. \\
\text { SOC) }\end{array}$ & $\begin{array}{l}\text { SOC- } \\
\text { specific } \\
\mathrm{C}_{\text {soil-derived }} \\
\text { (mg C g } \\
\text { SOC) }\end{array}$ & $\begin{array}{l}\text { Straw C- } \\
\text { specific } \\
\mathrm{C}_{\text {straw-derived }} \\
\\
\text { (mg C g g}^{-1} \\
\text { straw C) }\end{array}$ \\
\hline \multirow[t]{2}{*}{$\begin{array}{l}\text { Old } \\
\text { field }\end{array}$} & $\begin{array}{l}10 \\
{ }^{\circ} \mathrm{C}\end{array}$ & $\begin{array}{l}1.70 \\
(0.04)\end{array}$ & $\begin{array}{l}9.40 \\
(0.23)\end{array}$ & $7.59(0.20)$ & $47.78(1.08)$ & $\begin{array}{l}50.81 \\
(1.50)\end{array}$ & $\begin{array}{l}667.97 \\
(17.30)\end{array}$ \\
\hline & $\begin{array}{l}20 \\
{ }^{\circ} \mathrm{C}\end{array}$ & $\begin{array}{l}3.33 \\
(0.07)\end{array}$ & $\begin{array}{l}12.25 \\
(0.15)\end{array}$ & $8.83(0.13)$ & 93.63 (1.99) & $\begin{array}{l}96.16 \\
(1.23)\end{array}$ & $\begin{array}{l}776.82 \\
(11.78)\end{array}$ \\
\hline \multirow[t]{2}{*}{$\begin{array}{l}\text { Bare } \\
\text { fallow }\end{array}$} & $\begin{array}{l}10 \\
{ }^{\circ} \mathrm{C}\end{array}$ & $\begin{array}{l}1.11 \\
(0.04)\end{array}$ & $\begin{array}{l}8.73 \\
(0.30)\end{array}$ & $7.56(0.31)$ & 51.00 (1.88) & $\begin{array}{l}53.79 \\
(1.52)\end{array}$ & $\begin{array}{l}664.56 \\
(26.88)\end{array}$ \\
\hline & $\begin{array}{l}20 \\
{ }^{\circ} \mathrm{C}\end{array}$ & $\begin{array}{l}2.11 \\
(0.03)\end{array}$ & $\begin{array}{l}11.37 \\
(0.41)\end{array}$ & $9.09(0.33)$ & $96.94(1.24)$ & $\begin{array}{l}104.05 \\
(3.62)\end{array}$ & $\begin{array}{l}799.70 \\
(29.25)\end{array}$ \\
\hline \multicolumn{8}{|c|}{ ANOVA ( $P$-values) } \\
\hline \multicolumn{2}{|c|}{$\begin{array}{l}\text { Land-use } \\
\text { type (L) }\end{array}$} & $<0.001$ & 0.020 & 0.672 & 0.064 & 0.029 & 0.672 \\
\hline \multicolumn{2}{|c|}{$\begin{array}{l}\text { Temperature } \\
\text { (T) }\end{array}$} & $<0.001$ & $<.001$ & $<0.001$ & $<0.001$ & $<0.001$ & $<0.001$ \\
\hline \multicolumn{2}{|l|}{$L \times T$} & $<0.001$ & 0.722 & 0.569 & 0.981 & 0.283 & 0.569 \\
\hline
\end{tabular}

\section{3. $\delta^{13} \mathrm{C}$ value and priming effect}

The $\delta^{13} \mathrm{C}$ of total soil $\mathrm{CO}_{2}$ efflux from the straw-amended treatment became more negative over the duration of incubation, and the proportion of $\mathrm{CO}_{2}$ derived from SOM increased over time. Moreover, the $\delta^{13} \mathrm{C}$ values were significantly more negative at $20^{\circ} \mathrm{C}$ than at $10^{\circ} \mathrm{C}$ (Fig. S2).

Maize leaves addition enhanced the decomposition of native SOM (Table 2). The mean value of PE at the end of incubation was 60.78 and $108.05 \mu \mathrm{g} \mathrm{CO}_{2}-\mathrm{C} \mathrm{g}^{-1}$ soil in the bare fallow soil and the old field soil respectively, corresponding to 2.79 and $2.67 \mathrm{mg} \mathrm{CO}_{2}-\mathrm{C} \mathrm{g}^{-1} \mathrm{SOC}$ or relative increases of mineralization by $5.18 \%$ and $5.32 \%$ compared to the basal decomposition at $10^{\circ} \mathrm{C}$. The elevated temperature significantly increased the PE of the bare fallow soil $(P<0.05$, Fig. 2a). The mean value of PE of the bare fallow soil was $155.12 \mu \mathrm{g} \mathrm{CO}_{2}-\mathrm{C} \mathrm{g}^{-1}$ soil, corresponding to $7.30 \mathrm{mg} \mathrm{CO}_{2}-\mathrm{C} \mathrm{g}^{-1} \mathrm{SOC}$ at $20^{\circ} \mathrm{C}$. In contrast, temperature increase did not affect the magnitude of PE of the old field soil (Fig. 2a). 


\subsection{Soil net $\mathbf{N}$ mineralization}

Net $\mathrm{N}$ mineralization (NNM) was significantly higher in the old field soil than that in the bare fallow soil $(P<0.001$, Table 3). NNM was initially (0-60 days) inhibited by the presence of maize leaves, which was near or below zero. Afterwards (60-815 days), NNM was increased by the presence of maize leaves ( $P<$ $0.05)$. In the old field soil, NNM was significantly higher at $20^{\circ} \mathrm{C}$ than at $10^{\circ} \mathrm{C}$ during the first half of incubation period, but ended being similar at both temperatures (Fig. $3 a$ and b). In the bare fallow soil, despite a rapid decrease from day 330 to 550 , NNM ended being higher at $20^{\circ} \mathrm{C}$ than at $10^{\circ} \mathrm{C}$.

Table 3

ANOVA table of effects of soil land-use type (old field vs. bare fallow treatments), temperature $\left(10{ }^{\circ} \mathrm{C}\right.$ vs. $20^{\circ} \mathrm{C}$ ) and their interactions on net $\mathrm{N}$ mineralization (NNM), dissolved organic C (DOC) and microbial biomass $\mathrm{C}(\mathrm{MBC})$ in maize leaves-amended soils.

\begin{tabular}{|llllllllll|}
\hline Source & \multicolumn{1}{l}{ NNM } & \multicolumn{3}{c|}{ DOC } & \multicolumn{5}{c|}{ MBC } \\
\cline { 2 - 10 } & $\boldsymbol{d f}$ & $\boldsymbol{F}$ & $\boldsymbol{P}$ & $\boldsymbol{d f}$ & $\boldsymbol{F}$ & $\boldsymbol{P}$ & $\boldsymbol{d f}$ & $\boldsymbol{F}$ & $\boldsymbol{P}$ \\
\hline Land-use type (L) & 1 & 97.23 & $<0.001$ & 1 & 467.49 & $<0.001$ & 1 & 25.11 & $<0.001$ \\
\hline Temperature (T) & 1 & 143.95 & $<0.001$ & 1 & 13.44 & 0.001 & 1 & 115.93 & $<0.001$ \\
\hline Date (D) & 3 & 507.45 & $<0.001$ & 5 & 79.26 & $<0.001$ & 5 & 62.79 & $<0.001$ \\
\hline $\mathrm{L} \times \mathrm{T}$ & 1 & 8.59 & 0.006 & 1 & 1.87 & 0.178 & 1 & 0.33 & 0.571 \\
\hline $\mathrm{L} \times \mathrm{D}$ & 3 & 12.01 & $<0.001$ & 5 & 5.57 & $<0.001$ & 5 & 2.34 & 0.055 \\
\hline $\mathrm{T} \times \mathrm{D}$ & 3 & 142.53 & $<0.001$ & 5 & 7.94 & $<0.001$ & 5 & 9.94 & $<0.001$ \\
\hline $\mathrm{L} \times \mathrm{T} \times \mathrm{D}$ & 3 & 7.95 & $<0.001$ & 5 & 7.31 & $<0.001$ & 5 & 2.08 & 0.085 \\
\hline Error & 32 & & & 48 & & & 48 & & \\
\hline
\end{tabular}

\subsection{Dissolved organic carbon}

Maize leaves addition significantly increased dissolved organic carbon (DOC, per unit of SOC) content ( $p$ $<0.05)$. In straw-amended soils, DOC declined significantly over time throughout the incubation period $(P$ $<0.001$, Table 3; Fig. 3c and d), and DOC was significantly higher in the bare fallow soil than in the old field soil ( $P<0.001$, Table 3; Fig. $3 \mathrm{C}$ and d). Moreover, DOC at $10^{\circ} \mathrm{C}$ was initially higher than that at $20^{\circ} \mathrm{C}$, but ended being similar at both temperatures (significant temperature $\times$ date interaction, $P<0.001$, Table $3)$.

\subsection{Specific MBC}

Specific microbial biomass C (MBC, per unit of SOC) was significantly higher at $10^{\circ} \mathrm{C}$ than at $20^{\circ} \mathrm{C}(P<$ 0.001 , Fig. $3 e$ and $\mathrm{f}$, Table 3$)$. Maize leaves addition significantly increased MBC $(P<0.05)$, and the 
increase in the bare fallow soil was proportionally higher than that in the old field soil (196\% vs. $94 \%$ on average). Moreover, in the bare fallow soil, the increase in $\mathrm{MBC}$ by maize leaves addition was proportionally higher at $20^{\circ} \mathrm{C}$ than at $10^{\circ} \mathrm{C}(209 \%$ vs. $182 \%$ on average).

\section{Discussion}

\subsection{Temperature sensitivity of PE in the old field soil and the bare fallow soil}

As expected, the maize leaves amended soil communities degraded more $\mathrm{C}$ at $20^{\circ} \mathrm{C}$ than at $10{ }^{\circ} \mathrm{C}$ in both old field and bare fallow treatments. This also was the case in the control soil without maize leaves additions. The maize leaves amended microbial community had the ability to degrade additional $\mathrm{C}$ from the original soil, corresponding to a positive PE in both soil land-use types and temperatures. However, the temperature effect on PE did not follow the same patterns in the old field soil and the bare fallow soil. In the old field soil which contains both stabilized and labile SOM, the temperature effect on PE occurred transiently, and the PE in cold treated soil caught up to that in warm treated soil over time (Fig. S3). At the end of incubation, there was no significant difference of the total amount of PE at both temperatures. Our result is in accordance with previous studies which suggested that laboratory warming accelerates the instantaneous rate of PE (change in decomposition rate), but the amount of PE (cumulative amount of SOC primed) is not different amongst temperatures (Hopkins et al., 2014). This is because microbial activity can reach a higher peak in the warm treated soil than in the cold treated soil, which may result in a higher peak of PE (Dijkstra et al., 2011; Thiessen et al., 2013; Liu et al., 2019). However, the magnitude of PE is limited by substrate availability (Hopkins et al., 2014). The added fresh $\mathrm{C}$ is consumed more rapidly in the warm treated soil, and the temperature effect more rapidly diminishes than in the cold treated soil. Thus, at a given amount of fresh organic inputs, the cumulative amount of SOC primed would not increase with elevated temperature (Hopkins et al., 2014). However, few reports suggest that the amount of primed C was higher at warm than at cold temperature (Zhu and Cheng, 2011; Thiessen et al., 2013). This is accordance with our results that the temperature effect on PE lasted for a long time (Fig. S3), and the cumulative amount of SOC primed was significantly higher at $20^{\circ} \mathrm{C}$ than at $10^{\circ} \mathrm{C}$ in the bare fallow soil (Fig. 2c). This is conflict with an earlier discovery that PE is intrinsically insensitive to temperature (Ghee et al., 2013).

According to Thiessen et al. (2013), the amount of primed C per unit MBC (i.e. MBC-specific PE) was estimated based on the respiration and mean values of MBC. Then, in the bare fallow soil each unit of MBC primed higher amount of $\mathrm{C}$ in the warm than in the cold treated soil. This is consistent with the higher amount of PE in the warm treatment than in the cold treatment in the bare fallow soil. This finding suggests that temperature increase stimulates the efficiency of microbial communities in decomposing the original soil $\mathrm{C}$ in the presence of labile substrate. According to this observation, however, MBC-specific PE in the old field soil should also exhibit a similar temperature sensitivity because the old field soil rapidly loses the labile fraction of SOM over time. Yet, in the old field soil there was no difference of MBC- 
specific PE in the warm and cold treated soils. This corresponds to the observation of similar amount of PE at both temperatures in the old field soil. This finding suggests that the PE in the old field soil depends on the size of microbial biomass and the PE is indirectly related to temperature.

\subsection{Mechanisms mediating temperature sensitivity of PE}

According to the microbial activation hypothesis, the input of plant residues would likely increase substrate availability, microbial growth and extracellular enzyme activities in both soils (Blagodatsky et al., 2010; Thiessen et al., 2013; Shahbaz et al., 2017). In our study, the increased positive priming by warming for the bare fallow soil may be attributed to greater microbial growth and activity as evident from maize leaves-induced MBC increase in the bare fallow soil than the old field soil (Fang et al., 2018). This may have caused an increase of microbial accessibility and decomposability of the relatively stabilized SOM pool induced by the maize leaves input after the depletion of labile SOM in the bare fallow soil (Lenka et al., 2019). Similar mechanism was also proposed by Thiessen et al. (2013), who suggested that warming can increase extracellular enzyme activities, thus accelerate SOM mineralization. Furthermore, due to the hindering of low temperature on microbial activity, microbial communities may not be able to decompose the relatively stabilized SOM in the bare fallow soil, thus decreasing positive priming of SOM (Kuzyakov, 2010). By contrast, for the old field soil, the similarity in the cumulative amount of primed SOC at both temperatures was possibly due to high cumulative SOC mineralization in both control and maize leaves-treated soil at high temperature (Lenka et al., 2019). This observation suggests an equivalent accessibility and decomposability of SOM in the old field soil induced by the elevated temperature with or without the input of maize leaves. A similar observation of no significant difference of the magnitude of priming amongst temperatures was reported by Hopkins et al. (2014) and Ghee et al. (2013).

Microbial mining for $\mathrm{N}$ is another commonly proposed mechanism to explain the strength of priming responses (Zhu et al., 2014; Murphy et al., 2015), in which the addition of fresh organic substrates would stimulate the growth and activity of $\mathrm{N}$-acquiring microbes which in turn facilitate the decomposition of $\mathrm{N}$ rich SOM (Chen et al., 2013). Our result that the amount of primed $C$ was positively correlated with the amount of mineralized $\mathrm{N}(p<0.001$, Fig. $2 \mathrm{c})$ appears to support the microbial $\mathrm{N}$ mining hypothesis. The role of microbial $\mathrm{N}$ mining in priming $\mathrm{C}$ mineralization is also evidenced by our previous observation that soil $\mathrm{C}$ is positively correlated with net $\mathrm{N}$ mineralization (Zhang et al., 2021). Thus, we assumed that the temperature effect on priming in the bare fallow soil may also be caused by the temperature response of microbial $\mathrm{N}$ mining. Here, we observed that in maize leaves-treated bare fallow soil, temperature increase accelerated net $\mathrm{N}$ mineralization throughout the whole period of incubation. This is consistent with the increment of PE by warming in the bare fallow soil (Fig. S3). By contrast, in the maize leaves-treated old field soil, temperature increase only accelerated net $\mathrm{N}$ mineralization in the early stage, but had minor effect on net $\mathrm{N}$ mineralization in the later stage of incubation. This is in accordance with the temperature response of PE over time in the old field soil (Fig. S3).

It has been suggested that the magnitude of priming was positively correlated with extracellular enzymes that drive the priming process (i.e. C-, N-acquiring enzymes, Liu et al., 2019). These enzymes are 
temperature sensitive and would be activated by microbial demand for energy and nutrients (Allison and Vitousek, 2005; Liu et al., 2019). Liu et al. (2019) proposed that during the early stage of PE, N-acquiring enzymes dominated at higher temperature, and the rapid consumption of labile $\mathrm{C}$ at high temperature led to more and more $\mathrm{C}$ limitation for microorganisms, thus causing more production of $\mathrm{C}$-acquiring enzymes in the later stage of incubation. This is in accordance with our results that net $\mathrm{N}$ mineralization in maize leaves-treated bare fallow soil was generally higher at $20^{\circ} \mathrm{C}$ than at $10{ }^{\circ} \mathrm{C}$, while labile $\mathrm{C}$ (DOC) was lower at $20^{\circ} \mathrm{C}$ than at $10{ }^{\circ} \mathrm{C}$ (at the beginning and the end of incubation). However, for the old field soil, there was no significant difference of net $\mathrm{N}$ mineralization between the two temperatures in maize leavestreated soil at the end of incubation. Additionally, at higher temperature, net $\mathrm{N}$ mineralization was similar between control and maize leaves-treated soil at the end of incubation. This observation suggests that there was enough mineral $\mathrm{N}$ to meet microbial $\mathrm{N}$ demand even at a higher temperature in the old field soil.

\section{Conclusions}

In conclusion, our results demonstrate that temperature increase significantly enhanced maize leavesinduced PE of the relatively stabilized SOM in the bare fallow soil, which was not observed in the old field soil that contains both stabilized and labile SOM. The increase of microbial growth by maize leaves addition was higher in the bare fallow soil than in the old field soil, indicating an increase of microbial accessibility and decomposability of the relatively stabilize SOM pool induced by maize leaves input in the bare fallow soil. Furthermore, for maize leaves-treated soil, temperature increase significantly increased the rate of microbial $\mathrm{N}$ mining throughout the incubation in the bare fallow soil, but had minor effect on microbial $\mathrm{N}$ mining in the old field soil at the end of incubation. The different temperature responses of microbial growth and microbial $\mathrm{N}$ mining may explain the distinct temperature sensitivity of PE in the bare fallow soil and the old field soil. Our results have important implications for the feedback between SOM decomposition and climate warming, given the large stock of the relatively stabilized SOM in terrestrial ecosystems. Moreover, our results clearly highlight the need to pay attention to the temperature effect on PE of the relatively stabilized SOM which could enhance our capability to predict SOM decomposition and its feedback to climate warming.

\section{Abbreviations}

PE - priming effect; $\mathrm{C}$ - carbon; CO2 - carbon dioxide; SOC - soil organic carbon; SOM - soil organic matter; $\mathrm{N}$ - nitrogen; $\mathrm{MBC}$ - microbial biomass carbon; $\mathrm{DOC}$ - dissolved organic carbon; $\mathrm{C} / \mathrm{N}$ - the ratio of carbon to nitrogen; NNM - net nitrogen mineralization; WHC - water-holding capacity.

\section{Declarations}

\section{Acknowledgements}

This work was supported by the National Natural Science Foundation of China (31470625, 41630755 and 31988102), and the Natural Science Foundation of Zhejiang Province (LQ20D030001). 


\section{References}

1. Allison SD, Vitousek PM (2005) Responses of extracellular enzymes to simple and complex nutrient inputs. Soil Biol Biochem 37:937-944

2. Anderson DW, Paul EA (1984) Organo-mineral complexes and their study by radiocarbon dating. Soil Science Society America Journal 48:298-301

3. Barré P, Eglin T, Christensen BT, Ciais P, Houot S, Kätterer T, van Oort F, Peylin P, Poulton PR, Romanenkov V, Chenu C (2010) Quantifying and isolating stable soil organic carbon using long-term bare fallow experiments. Biogeosciences 7:3839-3850

4. Blagodatsky S, Blagodatskaya E, Yuyukina T, Kuzyakov Y (2010) Model of apparent and real priming effects: Linking microbial activity with soil organic matter decomposition. Soil Biol Biochem 42:1275-1283

5. Cardinael R, Eglin T, Guenet B, Neill C, Houot S, Chenu C (2015) Is priming effect a significant process for long-term SOC dynamics? Analysis of a 52-years old experiment. Biogeochemistry 123:203-219

6. Chen R, Senbayram M, Blagodatsky S, Myachina O, Dittert K, Lin X, Blagodatskaya E, Kuzyakov Y (2013) Soil $C$ and $N$ availability determine the priming effect: Microbial $N$ mining and stoichiometric decomposition theories. Glob Change Biol 20:2356-2367

7. Cheng W (1996) Measurement of rhizosphere respiration and organic matter decomposition using natural ${ }^{13} \mathrm{C}$. Plant Soil 183:263-268

8. Cheng W, Johnson DW, Fu S (2003) Rhizosphere effects on decomposition: controls of plant species, phenology, and fertilization. Soil Sci Soc Am J 67:1418-1427

9. Cheng W, Parton WJ, Gonzalez-Meler MA, Phillips R, Asao S, Mcnickle GG, Brzostek E, Jastrow JD (2014) Synthesis and modeling perspectives of rhizosphere priming. New Phytol 201:31-44

10. Conant RT, Drijber RA, Haddix ML, Parton WJ, Paul EA, Plante AF, Six J, Steinweg JM (2008) Sensitivity of organic matter decomposition to warming varies with its quality. Glob Change Biol 14:868-877

11. Craine JM, Morrow C, Fierer N (2007) Microbial nitrogen limitation increases decomposition. Ecology 88:2105-2113

12. Davidson EA, Janssens IA (2006) Temperature sensitivity of soil carbon decomposition and feedbacks to climate change. Nature 440:165-173

13. Demyan MS, Rasche F, Schulz E, Breulmann M, Müller T, Cadisch G (2012) Use of specific peaks obtained by diffuse reflectance Fourier transform mid-infrared spectroscopy to study the composition of organic matter in a Haplic Cher- nozem. Eur J Soil Sci 63:189-199

14. Derrien D, Plain C, Courty P-E, Gelhaye L, Moerdijk-Poortvliet TCW, Thomas F, Versini A, Zeller B, Koutika L-S, Boschker HTS, Epron D (2014) Does the addition of labile substrate destabilise old soil organic matter? Soil Biol Biochem 76:149-160

15. Dijkstra P, Thomas SC, Heinrich PL, Koch GW, Schwartz E, Hungate BA (2011) Effect of temperature on metabolic activity of intact microbial communities: Evidence for altered metabolic pathway 
activity but not for increased maintenance respiration and reduced carbon use efficiency. Soil Biol Biochem 43:2023-2031

16. Duboc O, Zehetner F, Djukic I, Tatzber M, Berger TW, Gerzabek MH (2012) Decomposition of European beech and Black pine foliar litter along an Alpine elevation gradient: Mass loss and molecular characteristics. Geoderma 189-190:522-531

17. Erhagen $B$, Ilstedt $U$, Nilsson MB (2015) Temperature sensitivity of heterotrophic soil $\mathrm{CO}_{2}$ production increases with increasing carbon substrate uptake rate. Soil Biol Biochem 80:45-52

18. Fang Y, Nazaries L, Singh BK, Singh BP (2018) Microbial mechanisms of carbon priming effects revealed during the interaction of crop residue and nutrient inputs in contrasting soils. Glob Change Biol 24:2775-2790

19. Feng J, Tang M, Zhu B (2021) Soil priming effect and its responses to nutrient addition along a tropical forest elevation gradient. Glob Change Biol. doi:10.1111/gcb.15587

20. Fontaine S, Barot S, Barre P, Bdioui N, Mary B, Rumpel C (2007) Stability of organic carbon in deep soil layers controlled by fresh carbon supply. Nature 450:10-14

21. Fontaine S, Henault C, Aamor A, Bdioui N, Bloor JMG, Maire V, Mary B, Revaillot S, Maron PA (2011) Fungi mediate long term sequestration of carbon and nitrogen in soil through their priming effect. Soil Biol Biochem 43:86-96

22. Frøseth RB, Bleken MA (2015) Effect of low temperature and soil type on the decomposition rate of soil organic carbon and clover leaves, and related priming effect. Soil Biol Biochem 80:156-166

23. Ghee C, Neilson R, Hallett PD, Robinson D, Paterson E (2013) Priming of soil organic matter mineralisation is intrinsically insensitive to temperature. Soil Biol Biochem 66:20-28

24. Guenet B, Juarez S, Bardoux G, Abbadie L, Chenu C (2012) Evidence that stable $C$ is as vulnerable to priming effect as is more labile $C$ in soil. Soil Biol Biochem 52:43-48

25. Guenet B, Camino-Serrano M, Ciais P, Tifafı M, Maignan F, Soong JL, Janssens IA (2018) Impact of priming on global soil carbon stocks. Glob Change Biol 24:1873-1883

26. Henneron L, Kardol P, Wardle DA, Cros C, Fontaine S (2020) Rhizosphere control of soil nitrogen cycling: a key component of plant economic strategies. New Phytol 228:1269-1282

27. Hopkins FM, Torn MS, Trumbore SE (2012) Warming accelerates decomposition of decades-old carbon in forest soils. Proc Natl Acad Sci USA 109:1753-1761

28. Hopkins FM, Filley TR, Gleixner G, Lange M, Top SM, Trumbore SE (2014) Increased belowground carbon inputs and warming promote loss of soil organic carbon through complementary microbial responses Francesca. Soil Biol Biochem 76:57-69

29. Hou Y, Chen Y, Chen X, He K, Zhu B (2019) Changes in soil organic matter stability with depth in two alpine ecosystems on the Tibetan Plateau. Geoderma 351:153-162

30. Jenkinson DS, Harkness DD, Vance ED, Adams DE, Harrison AF (1992) Calculating net primary production and annual input of organic-matter to soil from the amount and radiocarbon content of soil organic-matter. Soil Biol Biochem 24:295-308 
31. Jenkinson DS, Rayner JH (1977) The turnover of soil organic matter in some of the Rothamsted classical experiments. Soil Sci 123:298-305

32. Kirschbaum MUF (2004) Soil respiration under prolonged soil warming: Are rate reductions caused by acclimation or substrate loss? Glob Change Biol 10:1870-1877

33. Kuzyakov Y, Subbotina I, Chen H, Bogomolova I, Xu X (2009) Black carbon decomposition and incorporation into soil microbial biomass estimated by $14 \mathrm{C}$ labelling. Soil Biology Biochemistry 41:210-219

34. Kuzyakov Y (2010) Priming effects: Interactions between living and dead organic matter. Soil Biol Biochem 42:1363-1371

35. Lal R (2008) Carbon sequestration. Philosophical Transactions of the Royal Society B: Biological Sciences 363:815-830

36. Lefèvre R, Barré P, Moyano FE, Christensen BT, Bardoux G, Eglin T, Girardin C, Houot S, Kätterer T, van Oort F, Chenu C (2014) Higher temperature sensitivity for stable than for labile soil organic carbonEvidence from incubations of long-term bare fallow soils. Glob Change Biol 20:633-640

37. Lenka S, Trivedi P, Singh B, Singh BP, Pendall E, Bass A, Lenka NK (2019) Effect of crop residue addition on soil organic carbon priming as influenced by temperature and soil properties. Geoderma 347:70-79

38. Liang, Y., Han, X., Song, C., Li, H., 2011. Impacts of returning organic materials on soil labile organic carbon fractions redistribution of Mollisol in Northeast China. Scientia Agricultura Sinica 44, 35653574 .

39. Lin J, Zhu B, Cheng W (2015) Decadally cycling soil carbon is more sensitive to warming than fastercycling soil carbon. Glob Change Biol 21:4602-4612

40. Liu Q, Xu X, Wang H, Blagodatskaya E, Kuzyakov Y (2019) Dominant extracellular enzymes in priming of SOM decomposition depend on temperature. Geoderma 343:187-195

41. Lu J, Dijkstra FA, Wang P, Cheng W (2018) Rhizosphere priming of grassland species under different water and nitrogen conditions: a mechanistic hypothesis of C-N interactions. Plant Soil 429:303-319

42. Lyu M, Nie Y, Giardina CP, Vadeboncoeur MA, Ren Y, Fu Z, Wang M, Jin C, Liu X, Xie J (2019) Litter quality and site characteristics interact to affect the response of priming effect to temperature in subtropical forests. Funct Ecol 33:2226-2238

43. Murphy CJ, Baggs EM, Morley N, Wall DP, Paterson E (2015) Rhizosphere priming can promote mobilisation of N-rich compounds from soil organic matter. Soil Biol Biochem 81:236-243

44. Nault JR, Preston CM, Trofymow JA, Tony Fyles J, Kozak L, Siltanen M, Titus B (2009) Determination of organic and inorganic carbon in forest soil samples by mid-infrared spectroscopy and partial least squares regression. Soil Sci 64:1167-1175

45. Nocentini C, Guenet B, Di Mattia E, Certini G, Bardoux G, Rumpel C (2010) Charcoal mineralisation potential of microbial inocula from burned and unburned forest soil with and without substrate addition. Soil Biol Biochem 42:1472-1478 
46. Nunan N, Lerch TZ, Pouteau V, Mora P, Changey F, Kätterer T, Giusti-Miller S, Herrmann AM (2015) Metabolising old soil carbon: Simply a matter of simple organic matter? Soil Biol Biochem 88:128136

47. Perveen N, Barot S, Alvarez G, Klumpp K, Martin R, Apaport R, Herfurth A, Louault D, Fontaine F, S (2014) Priming effect and microbial diversity in ecosystem functioning and response to global change: a modeling approach using the SYMPHONY model. Glob Change Biol 20:1174-1190

48. Senesi N, D’Orazio V, Ricca G (2003) Humic acids in the first generation of EUROSOILS. Geoderma 116:325-344

49. Shahbaz M, Kuzyakov Y, Sanaullah M, Heitkamp F, Zelenev V, Kumar A, Blagodatskaya E (2017) Microbial decomposition of soil organic matter is mediated by quality and quantity of crop residues: mechanisms and thresholds. Biol Fertil Soils 53:287-301

50. Smidt E, MeissI K (2007) The applicability of Fourier transform infrared (FT-IR) spectroscopy in waste management. Waste Manag 27:268-276

51. Smolander A, Kitunen V (2002) Soil microbial activities and characteristics of dissolved organic $C$ and $\mathrm{N}$ in relation to tree species. Soil Biol Biochem 34:651-660

52. Soil Survey, Staff (1999) Soil Taxonomy. A basic system of soil classification for making and interpreting soil surveys, 2nd ed., Agricultural Handbook 436. Natural Resources Conservation Service. USDA, Washington DC, USA, pp. 869

53. Song M, Jiang J, Xu X, Shi P (2011) Correlation between $\mathrm{CO}_{2}$ efflux and net nitrogen mineralization and its response to external $\mathrm{C}$ or $\mathrm{N}$ supply in an Alpine meadow soil. Pedosphere 21:666-675

54. Stevenson FJ (1994) Humus Chemistry. Genesis, Composition, Reactions, second edn. Wiley, New York, p 496

55. Thiessen S, Gleixner G, Wutzler T, Reichstein M (2013) Both priming and temperature sensitivity of soil organic matter decomposition depend on microbial biomass - An incubation study. Soil Biol Biochem 57:739-748

56. Tian Q, Wang X, Wang D, Wang M, Liao C, Yang X, Liu F (2017) Decoupled linkage between soil carbon and nitrogen mineralization among soil depths in a subtropical mixed forest. Soil Biol Biochem 109:135-144

57. Trumbore SE, Vogel JS, Southon JR (1989) AMS ${ }^{14} \mathrm{C}$ measurements of fraction- ated soil organic matter: an approach to deciphering the soil carbon cycle. Radiocarbon 31:644-654

58. Vance ED, Brookes PC, Jenkinson DS (1987) An extraction method for measuring soil microbial biomass C. Soil Biol Biochem 19:703-707

59. Vestergård M, Reinsch S, Bengtson P, Ambus P, Christensen S (2016) Enhanced priming of old, not new soil carbon at elevated atmospheric $\mathrm{CO}_{2}$. Soil Biology Biochmistry 100:140-148

60. Xiao C, Guenet B, Zhou Y, Su J, Janssens IA (2015) Priming of soil organic matter decomposition scales linearly with microbial biomass response to litter input in steppe vegetation. Oikos 124:649657

Page 18/21 
61. Zhang X, Han X, Yu W, Wang P, Cheng W (2017) Priming effects on labile and stable soil organic carbon decomposition: Pulse dynamics over two years. PLoS ONE 12:e0184978

62. Zhang X, Zhu B, Yu F, Cheng W (2021) Plant inputs mediate the linkage between soil carbon and net nitrogen mineralization. Sci Total Environ 790:148208

63. Zhu B, Cheng W (2011) Rhizosphere priming effect increases the temperature sensitivity of soil organic matter decomposition. Glob Change Biol 17:2172-2183

64. Zhu B, Gutknecht JLM, Herman DJ, Keck DC, Firestone MK, Cheng W (2014) Rhizosphere priming effects on soil carbon and nitrogen mineralization. Soil Biol Biochem 76:183-192

\section{Figures}
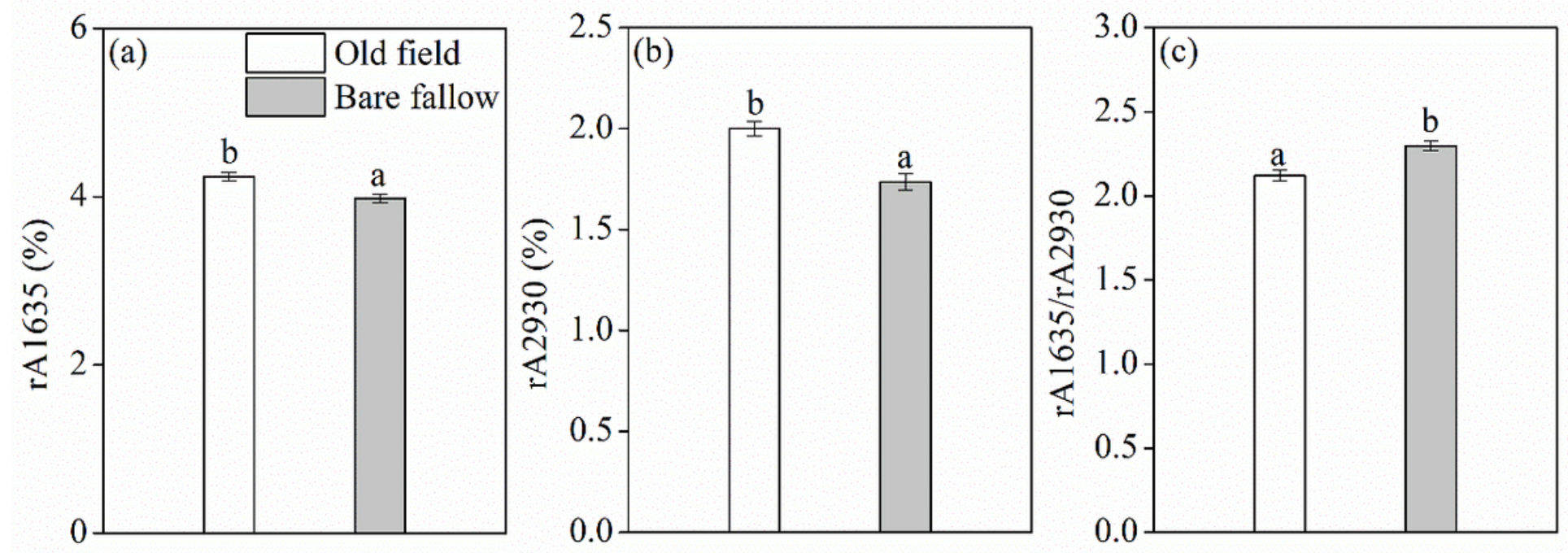

\section{Figure 1}

Changes of rA1635 (a), rA2930 (b) and soil resistance index (ratio of rA1635/rA2930, c) based on Fourier-transform infrared (FTIR) spectroscopy for the old field and bare fallow soils. Error bars indicate standard errors of the mean $(n=3)$. 


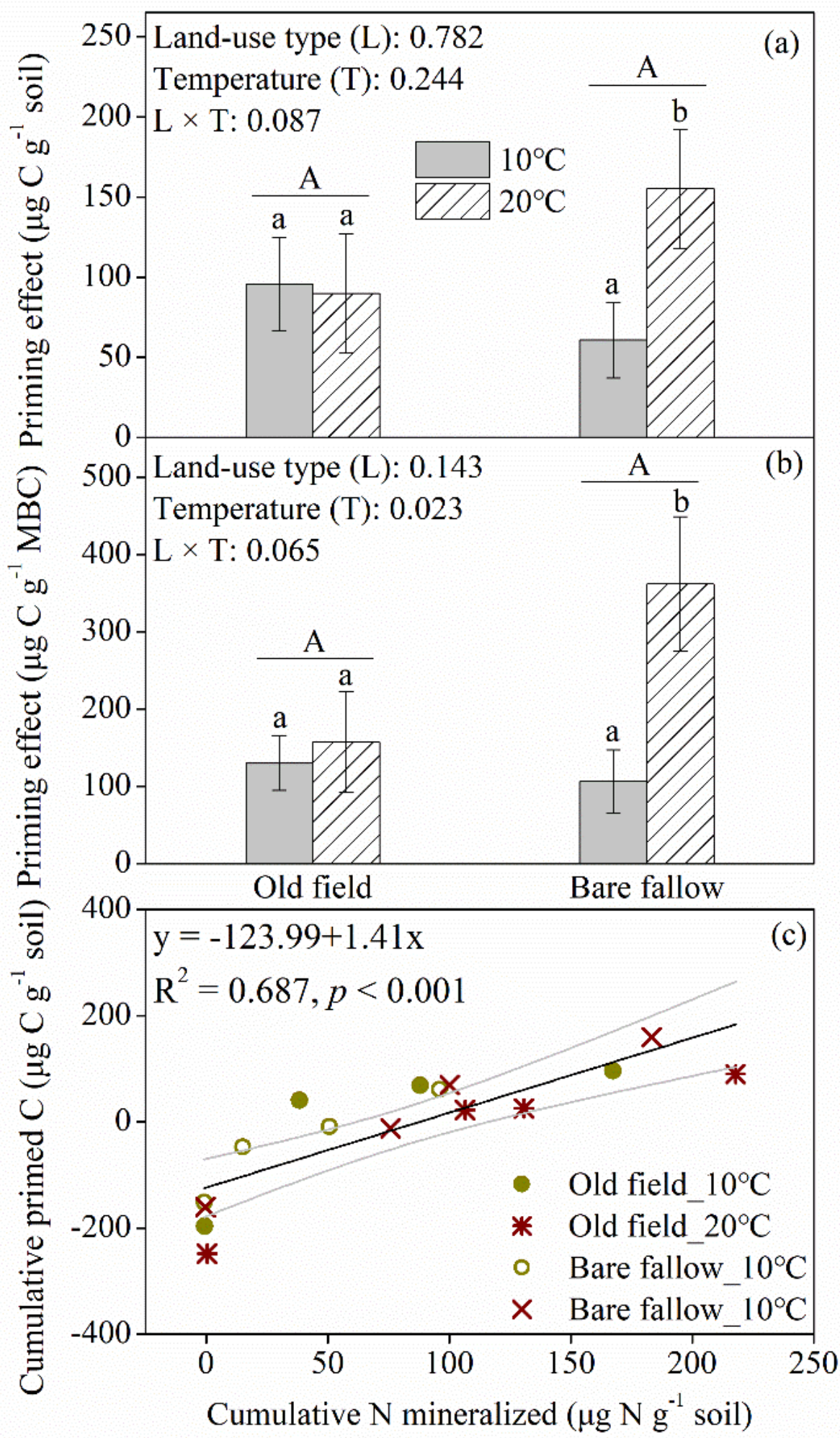

Figure 2

Priming effect (a) (expressed as $\mu \mathrm{g} \mathrm{C} \mathrm{g-1} \mathrm{soil),} \mathrm{MBC-specific} \mathrm{priming} \mathrm{effect} \mathrm{(b)} \mathrm{(expressed} \mathrm{as} \mu \mathrm{g} \mathrm{C} \mathrm{g-1}$ $\mathrm{MBC}$ ) and the linear regression between cumulative $\mathrm{N}$ mineralized and cumulative primed $\mathrm{C}$ (c) in old field and bare fallow soils. Error bars indicate standard errors of the mean $(n=4)$. Different letters represent significant differences between the low $\left(10^{\circ} \mathrm{C}\right)$ and high $\left(20^{\circ} \mathrm{C}\right)$ temperature treated soils within each soil treatment (t-test; $\mathrm{P}<0.05)$. The data of cumulative $\mathrm{N}$ mineralized and cumulative primed 
C are calculated from destructive samplings at 60, 330, 550 and 815 days. Grey lines represent the $95 \%$ confidence interval of the linear regression.

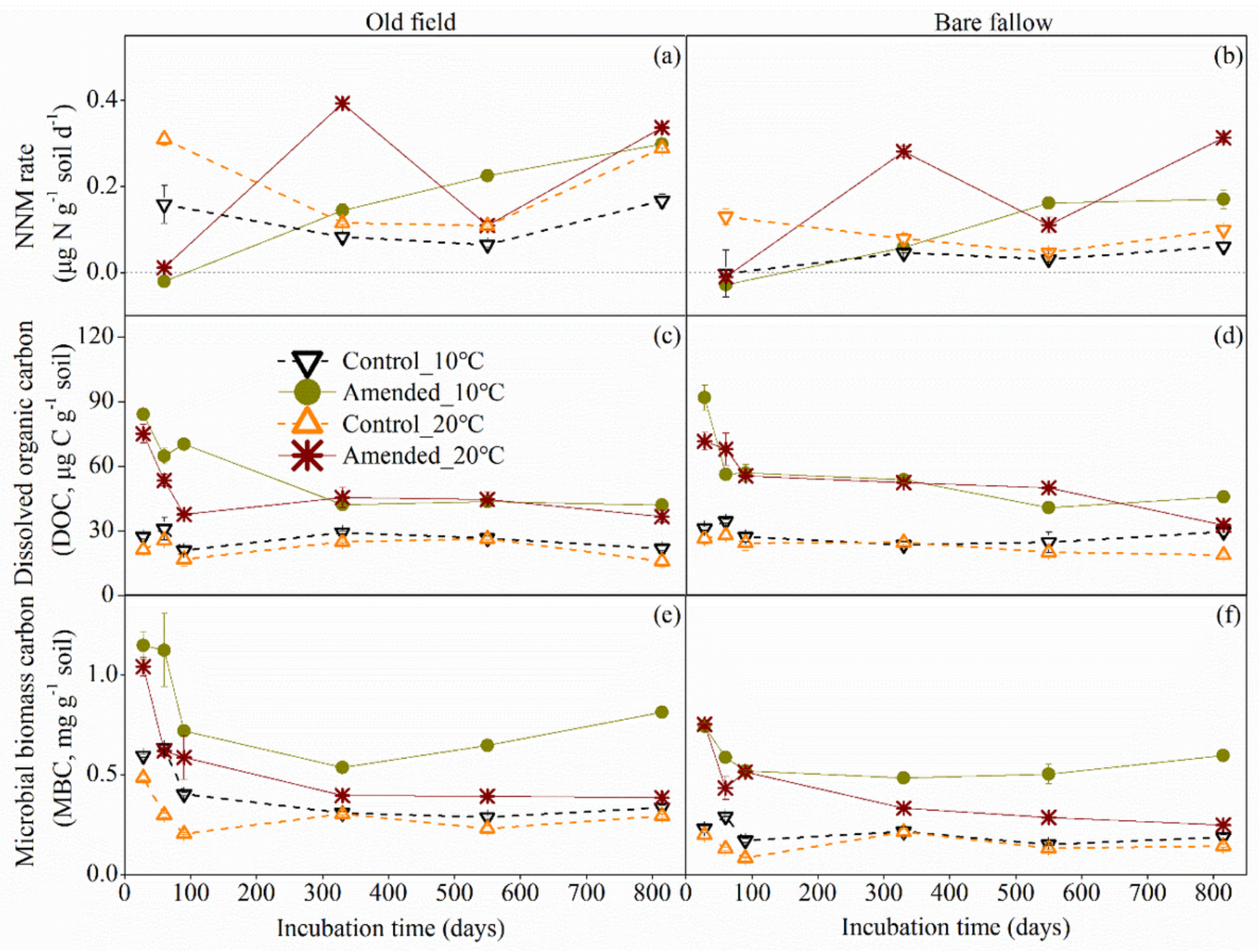

Figure 3

Net $\mathrm{N}$ mineralization rate (NNM) (a \& b), dissolved organic carbon (DOC) (c \& d) and microbial biomass carbon (MBC) (e \& f) in maize leaves-amended and non-amended control soils at low $\left(10^{\circ} \mathrm{C}\right)$ and high $\left(20^{\circ} \mathrm{C}\right)$ temperature treatments. Error bars indicate standard errors of the mean $(n=3)$.

\section{Supplementary Files}

This is a list of supplementary files associated with this preprint. Click to download.

- Supplementaryinformation.docx 